DOI

\title{
ВИКОРИСТАННЯ МЕТЕОСПАЗМІЛУ ТА КАРВЕДИЛОЛУ В ЛІКУВАННІ ХВОРИХ НА ТОКСИЧНІ ФОРМИ ЗОБА ТА СИНДРОМ ПОДРАЗНЕНОГО КИШЕЧНИКА: ВІДДАЛЕНІ РЕЗУЛЬТАТИ
}

\section{Буковинський державний медичний університет, м. Чернівці}

РЕЗЮМЕ. Використання метеоспазмілу та карведилолу у хворих на токсичні форми зоба для корекції функціональних порушень кишечника $\epsilon$ доцільним та ефективним для зниження надмірної концентрації серотоніну та відновлення вегетативного балансу.

КЛЮчОВІ СЛОВА: токсичні форми зоба, синдром подразненого кишечника, серотонін, вегетативний дисбаланс.

Вступ. Серед усіх захворювань ЩЗ найрозповсюдженішими $\epsilon$ токсичні форми зоба (ТФЗ). Тиреотоксикоз, як синдром підвищеного вмісту тиреоїдних гормонів, трапляється у 3 \% жінок і 0,3\% чоловіків, навіть у районах із нормальним йодним забезпеченням [6]. Поширеність синдрому тиреотоксикозу в Україні (станом на 01.01.2012р.) становила 117,9 на 100 тис. населення, захворюваність населення України на тиреотоксикоз у 2011 р. становила 13,6 на 100 тис. населення [1].

Тиреотоксикоз чинить патологічний вплив на всі органи та системи організму, особливо на діяльність травної системи $[1,3]$. Ентеральні розлади трапляються у 60 \% хворих на ТФЗ, однак, здебільшого вони залишаються поза увагою клініцистів $[3,5]$. Проблема поєднаної патології - перебіг синдрому подразненого кишечника (СПК) на тлі тиреотоксикозу вивчена недостатньо різнобічно. Майже не досліджено взаємовплив різних гормонів та біологічно активних речовин на перебіг захворювання [4]. Не до кінця розкриті механізми впливу серотоніну та вегетативного дисбалансу на скоротливу здатність кишечника [2]. Це все утруднює розробку патогенетично обґрунтованого лікування хворих на ТФЗ із СПК.

Мета роботи полягала в аналізі віддалених результатів лікування хворих на токсичні форми зоба з синдромом подразненого кишечника за використання метеоспазмілу та карведилолу.

Матеріал та методи дослідження. Дослідження проведені в 106 хворих на ТФЗ (субкомпенсований тиреотоксикоз середнього ступеня тяжкості, обумовлений дифузним, вузловим та змішаним токсичним зобом II-III ст.).

Усім хворим було проведено комплексне обстеження, що включало збір скарг, анамнезу, об'єктивне обстеження, лабораторні та інструментальні дослідження.

Діагноз тиреотоксикозу встановлювали на основі клінічних даних, результатів УзД щито- подібної залози, визначення рівня гормонів ТТГ, вільних Т3, Т4.

Діагноз СПК встановлювали на основі Римських критеріїв III (2006 р.).

Рівень серотоніну досліджували методом IФА, використовуючи реактиви фірми «DRG» (Hiмеччина). Для визначення варіабельності серцевого ритму (ВСР) проводили холтерівське моніторування ЕКГ за допомогою 3-канальної комбінованої холтерівської системи «EC-3H/ABP» (Labtech, Угорщина). Оцінку якості життя проводили за допомогою опитувальника MOS SF - 36.

Усіх хворих було поділено на 3 групи. До 1-ї групи увійшли 35 хворих на ТФЗ з СПК з переважанням проносів, до 2-ї- 34 пацієнти з тиреотоксикозом з СПК з перевагою закрепів. 3-ю групу склали 37 хворих на ТФЗ без ознак порушення моторно-евакуаторної функції кишечника.

Усі пацієнти отримували базисну терапію тиреотоксикозу, яка включала препарати імідазолу, $\beta$-адреноблокатор (пропранолол) та заспокійливі засоби. Пацієнти 1-ї та 2-ї груп отримували, окрім базисної терапії, метеоспазміл у дозі 1 капсула 3 рази на добу та карведилол (замість пропранололу) у дозі 12,5 мг 1 раз на добу.

Тривалість терапії складала 1 місяць з повторним курсом упродовж 1-го місяця через півроку. Дослідження проводили до початку лікування та через рік. Контролем слугували 20 практично здорових осіб.

Статистична обробка результатів досліджень проводилась з використанням електронних таблиць Microsoft $\circledast$ Office Excel (build 11.5612.5703) та програми для статистичної обробки Statgraphics Plus 5.1 Enterprise edition (®Statistical Graphics согр. 2001). Вірогідності різниці між отриманими даними оцінювали за коєфіцієнтом Стьюдента (t). За вірогідну приймали різницю при р<0,05.

Результати й обговорення. При оцінці рівня тиреоїдних гормонів через рік після проведеного 
Огляди літератури, оригінальні дослідження, погляд на проблему

лікування встановлено, що у хворих всіх груп концентрація ТТГ, вільних Т3 та Т4 не відрізнялась від контрольних показників, що свідчить про ефективність запропонованого комплексного лікування для досягнення тиреоїдного гомеостазу.

При аналізі динаміки концентрації серотоніну в плазмі крові через рік після лікування виявлено, що використання комплексного лікування приводило до його стабілізації. Так, у 1-й групі концентрація серотоніну склала 152,34ะ19,25 нг/мл, і була вірогідно нижчою від такої до початку лікування $(p<0,01)$, у пацієнтів 2-ї групи через рік після лікування концентрація серотоніну склала 156,54ะ21,18 нг/мл, і була вірогідно нижчою від такої до початку лікування $(p<0,05)$. При цьому рівень серотоніну у пацієнтів 1-ї та 2-ї груп практично не відрізнявся.

При оцінці ВСР у віддалений період спостереження встановлено, що частота серцевих скорочень (ЧСС) через рік після лікування була вірогідно нижчою, ніж до його початку у всіх 3-х виділених групах і сягала фізіологічних параметрів. Величина SDNN у пацієнтів 1-ї та 3-ї груп практично не змінювалась, а у 2-й мала невірогідну тенденцію до зростання, значно перевищуючи аналогічний показник до лікування. Показник SDANN через рік після лікування мав тенденцію до зростання, однак вірогідні відмінності виявлено лише у пацієнтів 2-ї групи. Показник гMSSD високо вірогідно знижувався в 1-й групі, майже не відрізнявся від такого до початку лікування у пацієнтів 2-ї та 3-ї груп. Параметри рNN50 у пацієнтів 1-ї групи були вірогідно нижчими за аналогічний показник до початку лікування, у хворих 2-ї та 3-ї груп - високовірогідно зростали. Аналіз показників ВСР

\section{ЛІТЕРАТУРА}

1. Аналіз діяльності ендокринологічної служби України у 2010 році та перспективи розвитку медичної допомоги хворим з ендокринною патологією / О. С. Ларін, В. І. Паньків, М. І. Селіваненко [та ін.] // Міжнар. ендокр. журн. - 2011. - №3 (35). - С. 10-18.

2. Вейн А. М. Вегетативные расстройства / А. М. Вейн. - М, 2001. - С. 167-174.

3. Дорофеев А. Э. Возможности применения отилония бромида у больных с синдромом раздраженного кишечника / А. Э. Дорофеев, Н. Н. Руденко, О. А. Рассохина // Гастроэнтерология. - 2010. - № 313. - С. 39-40. свідчить про відновлення балансу між ланками вегетативної нервової системи за використання розробленої терапії.

При аналізі динаміки показників суб'єктивної оцінки якості життя пацієнтів через рік від початку лікування виявлені суттєві відмінності у виділених групах хворих. Найвищі параметри, наближені до оптимальних, спостерігались у хворих 3-ї групи, хоча динаміка показників до та після лікування була найменш вираженою. Дещо нижчі показники якості життя характерні для пацієнтів 2-ї групи. Найнижчі параметри якості життя після лікування виявлено у пацієнтів 1-ї групи. Разом з тим, у цій групі спостерігалась найвираженіша позитивна динаміка якості життя після проведеного лікування, що свідчить про його ефективність.

Висновки. У віддалений період спостереження у хворих на токсичні форми зоба з синдромом подразненого кишечника за використання метеоспазмілу та карведилолу спостерігається нормалізація рівня тиреоїдних гормонів, серотоніну в плазмі крові, відновлення вегетативного балансу, про що свідчить зростання параметрів варіабельності серцевого ритму.

Проведене лікування приводить до покращення якості життя, особливо у пацієнтів з гіпермоторними порушеннями кишечника.

Перспективи подальших досліджень. Перспективним $є$ вивчення лікування хворих на токсичні форми зоба та синдром подразненого кишечника з урахуванням поліморфізму генів, функція яких пов'язана з серотоніновим балансом та вегетативною регуляцією.

4. Звягинцева Т. Д. Агонисты серотониновых рецепторов и синдром раздраженного кишечника/ Т. Д. Звягинцева, А. И. Чернобай // Гастроэнтер. - 2010. - № 313. С. 14-17.

5. Зимницкая Т. В. Влияние содержания серотонина и гистамина в крови у детей с синдромом раздраженного кишечника на показатели биоэлектрической активности толстой кишки / Т. В. Зимницкая // Современная педиатрия. - 2009. - № 1(23). - С. 114-116.

6. Паньків В.ІІ. Практична тиреїдологія : монографія / В. І. Паньків. - Донецьк : Заславський О. Ю., 2011. - 224 с.

\title{
THE USE OF METEOSPAZMIL AND CARVEDILOLIN TREATMENT OF PATIENTS WITH GOITERTOXIC FORMS AND IRRITABLE BOWEL SYNDROME
}

\author{
OI. I. Moskaliuk, V. I. Moskaliuk
}

\section{Bukovynian State Medical University}

SUMMARY. The use of meteospazmil and carvedilol in patients with toxic goiter forms for correction of functional disorders of the intestine is appropriate and effective for reduction of excessive serotonin concentration and restoration of autonomic balance.

KEY WORDS: Toxicforms of goiter, irritable bowel syndrome, serotonin, autonomic imbalance. 